\title{
Comparative study of hyperpure chlorine dioxide with two other irrigants regarding the viability of periodontal ligament stem cells
}

\author{
Orsolya Láng ${ }^{1} \cdot$ Krisztina S. Nagy ${ }^{2,3}$ • Julia Láng ${ }^{1} \cdot$ Katalin Perczel-Kovách ${ }^{2,4} \cdot$ Anna Herczegh $^{5} \cdot$ Zsolt Lohinai $^{5}$. \\ Gábor Varga $^{2}$ • László Köhidai ${ }^{1}$ (1)
}

Received: 16 June 2020 / Accepted: 1 October 2020 / Published online: 12 October 2020

(C) The Author(s) 2020

\begin{abstract}
Objectives Periodontal ligament stem cells (PDLSCs) have an underlined significance as their high proliferative capacity and multipotent differentiation provide an important therapeutic potential. The integrity of these cells is frequently disturbed by the routinely used irrigative compounds applied as periodontal or endodontic disinfectants (e.g., hydrogen peroxide $\left(\mathrm{H}_{2} \mathrm{O}_{2}\right)$ and chlorhexidine (CHX)). Our objectives were (i) to monitor the cytotoxic effect of a novel dental irrigative compound, chlorine dioxide $\left(\mathrm{ClO}_{2}\right)$, compared to two traditional agents $\left(\mathrm{H}_{2} \mathrm{O}_{2}, \mathrm{CHX}\right)$ on PDLSCs and (ii) to test whether the aging factor of PDLSC cultures determines cellular responsiveness to the chemicals tested.

Methods Impedimetry (concentration-response study), WST-1 assays (WST $=$ water soluble tetrazolium salt), and morphology analysis were performed to measure changes in cell viability induced by the 3 disinfectants; immunocytochemistry of stem cell markers (STRO-1, CD90, and CD105) measured the induced mesenchymal characteristics.

Results Cell viability experiments demonstrated that the application of $\mathrm{ClO}_{2}$ does not lead to a significant decrease in viability of PLDSCs in concentrations used to kill microbes. On the contrary, traditional irrigants, $\mathrm{H}_{2} \mathrm{O}_{2}$, and CHX are highly toxic on PDLSCs. Aging of PLDSC cultures (passages 3 vs. 7) has characteristic effects on their responsiveness to these agents as the increased expression of mesenchymal stem cell markers turns to decreased.

Conclusions and clinical relevance While the active ingredients of mouthwash $\left(\mathrm{H}_{2} \mathrm{O}_{2}, \mathrm{CHX}\right)$ applied in endodontic or periodontitis management have a serious toxic effect on PDLSCs, the novel hyperpure $\mathrm{ClO}_{2}$ is less toxic providing an environment favoring dental structure regenerations during disinfectant interventions.
\end{abstract}

Keywords Chlorine dioxide $\cdot$ Dental stem cells $\cdot$ PDLSC $\cdot$ Viability $\cdot$ Toxicity $\cdot$ Hydrogen peroxide $\cdot$ Chlorhexidine

\section{Introduction}

Electronic supplementary material The online version of this article (https://doi.org/10.1007/s00784-020-03618-5) contains supplementary material, which is available to authorized users.

László Köhidai

kohlasz2@gmail.com

1 Department of Genetics, Cell- and Immunobiology, Semmelweis University, Budapest, Hungary

2 Department of Oral Biology, Semmelweis University, Budapest, Hungary

3 Laboratory of Nanochemistry, Department of Biophysics and Radiation Biology, Semmelweis University, Budapest, Hungary

4 Department in Community Dentistry, Semmelweis University, Budapest, Hungary

5 Department of Conservative Dentistry, Semmelweis University, Budapest, Hungary
For the last two decades, the discovery of the dental stem cells (DSCs) has opened new perspectives in regenerative dentistry and medicine. The first source of these oral cells with mesenchymal stem cell (MSC) properties was the human dental pulp [1], and subsequently, four more types of DSCs were gained from different tooth-related tissues, such as pulp of exfoliated deciduous teeth [2], periodontal ligament (PDL) [3], dental follicle [4], and apical papilla [5]. The common feature of these DSCs is that they exhibit fibroblast-like morphology with good proliferative potential and fulfill the minimal criteria of MSC characteristics, such as adherence to plastic surface, expression of certain surface antigens (e.g., more than $95 \%$ of the cell population express CD73, CD90, and CD105, and less than $2 \%$ express hematopoietic markers), and capacity for multipotent differentiation in vitro [6]. Recent studies 
provided evidence for a wide range of plasticity of these SCs and their ability to repair tooth-related tissues or bone in vivo. Additionally, as DSCs are easily accessible and lack strict ethical concern conversely from their embryonic counterparts, they represent favorable tools also for the therapy of neurodegenerative disorders (e.g., Alzheimer or Parkinson diseases) or cardiac ischemia $[7,8]$.

Of the abovementioned DSCs, the PDLSCs are of great significance both in theoretical and practical aspects. Due to the lack of consensus criteria defining dental stem cells based on the surface antigen expression pattern, in most of the studies, PDLSCs are characterized by positivity for MSC markers. PDLSCs were found to express the STRO-1 antigen [3, 9] identified first in bone marrow stromal cells [10] - and other MSC markers, such as CD13, CD29, CD44, CD59, CD90, and CD105 [7]. However, some investigation also revealed embryonic stem cell marker positivity (e.g., Oct-4) of these cells [9]. PDLSCs exhibit multipotent differentiation capacity. In vitro, these cells are able to differentiate into osteogenic, adipogenic [3], chondrogenic [11], neurogenic [12], and myogenic [13] lineages. In vivo, they have fundamental importance in the physiology of PDL, which does not only anchor the cementum covering the root to the alveolar bone but also contributes to its nutrition, homeostasis, and repair. The significant regenerative potential of PLDSCs allows these cells to contribute the spontaneous or medically induced restorative mechanisms of the periodontal region $[14,15]$. The differentiation potential of these stem cells is similar to pericytes, while their immunomodulatory character is also well described $[16,17]$. The integrity of these cells in the PDL is vital for the whole life of the tooth. One of the longstanding goals of dental care is to keep the periodontium in good health and to reconstruct it when destroyed by the periodontal disease. Therefore, it is of paramount importance to know the effect of the disinfectant substances used routinely in the oral cavity on the physiological processes of these stem cells.

In conventional dental care, irrigative agents are frequently used to eliminate the bacteria from different regions, e.g., outer root surface in case of periodontal or root canal surface in endodontic treatment. Due to the multispecies composition of the biofilm, the effective antibacterial irrigative have a relatively broad spectrum and multiple intracellular targets, which reduce the frequency of resistant cases. Topical antiseptics, such as chlorhexidine ( $\mathrm{CHX})$ and hydrogen peroxide $\left(\mathrm{H}_{2} \mathrm{O}_{2}\right)$, which are routinely applied as disinfectants in dentistry, correspond to these criteria. However, antiseptics, unlike antibiotics, are potentially toxic not only to the infectious microbes but to the host cells as well. Recently, a well-known biocide, chlorine dioxide $\left(\mathrm{ClO}_{2}\right)$, has been invented in the dental care, as its application was suggested for disinfection of the air of dental offices [18] and also of dental instruments [19].
$\mathrm{H}_{2} \mathrm{O}_{2}$ has been acknowledged as an effective disinfecting tool in the dentistry for centuries. Nowadays, it is used in 3\% for hemostasis and maximum in $6 \%$ in EU or $38 \%$ in the USA for bleaching [20]. But the concentration- and time-dependent cytotoxic effects of $\mathrm{H}_{2} \mathrm{O}_{2}$ are well described in human PDL cells [20]. RANK ligand-induced activation was described as potential trigger mechanism of this action besides its free radical activity [21].

CHX is a cationic diphenyl compound that acts as a broadspectrum bactericidal agent. It is effective against both Grampositive and Gram-negative bacteria and fungi as well. Based on its chemical characteristics, CHX interacts with the anionic phosphate residue of the lipid molecules and causes severe damage to the cytoplasmic membrane and the peptidoglycan layer of microorganisms [22]. Its therapeutic concentration used in clinical dentistry is in the range $0.05-0.2 \%$ as an oral rinse and in $0.2-6 \%$ as endodontic irrigation. Even low concentrations of CHX $(0.0001 \%)$ has been shown to be toxic for gingival fibroblasts, reducing the production of collagen and non-collagen proteins [23]. In human PDL cells, the cytotoxic effects of CHX are concentration- and time-dependent and associated with protein synthesis inhibition [24]. Other studies show that the survival rate of equine fibroblasts increases linearly with decreasing concentrations of $\mathrm{CHX}$, with $50 \%$ of survival at $0.005 \% \mathrm{CHX}$ [25]. Exposure of dental root surfaces to CHX $(0.12 \%)$ significantly inhibited subsequent attachment of gingival fibroblasts [26]. In addition, the attachment of PDL cells onto the root surface and their morphology were adversely altered with 0.2 to $2.0 \%$ CHX pretreatment of the root surface [27].

Thus, we would need a disinfectant which is less toxic for humans but is still effective against the microbes. Lubbers and coworkers [28] have shown in 1982 that chlorine dioxide, "the ideal biocide" [29], might meet these criteria. The use of chlorine dioxide as an antiseptic was hindered, because $\mathrm{ClO}_{2}$ solutions of that time were contaminated with other chemicals and were not stable enough. In 2006, however, a new membrane separation process was invented [30], which can produce hyperpure and therefore significantly more stable $\mathrm{ClO}_{2}$ solutions [31]. Such solutions are commercially available in Hungary since 2008 under the name of Solumium (https:// www.solumium.com/) and applied in dental care since that time [32]. Their favorable antimicrobial efficacy was demonstrated against oral pathogen bacteria $[33,34]$. $\mathrm{ClO}_{2}$ can be also used as intracanal bleaching substance [24]. It was also demonstrated to be less toxic to equine fibroblasts than $\mathrm{CHX}$ [21]. The cytotoxic effect of $\mathrm{ClO}_{2}$ on human gingival fibroblasts was shown to be only in the millimolar range $\left(\mathrm{LD}_{50}=0.16 \mathrm{mM}\right)$, while low concentrations of $\mathrm{ClO}_{2}$ did not induce apoptotic responses [25]. $\mathrm{ClO}_{2}$ is a sizeselective antimicrobial agent [35] which explains theoretically why $\mathrm{ClO}_{2}$ solutions lethal for microbes are not harmful to humans. Thus, the remarkable selectivity of $\mathrm{ClO}_{2}$ between 
humans and bacteria is based not on their different biochemistry, but on their different sizes. Based on its previously discussed properties, hyperpure chlorine dioxide solutions should be highly suitable for medical and dental applications. However, a major obstacle of the widespread human clinical application is that practically no published data are available about the possible toxic effects of $\mathrm{ClO}_{2}$ on dental cells.

Thus, the purposes of the present study were (i) to compare the cell physiological effects (cytotoxicity and viability) of the three dental irrigative compounds $\left(\mathrm{H}_{2} \mathrm{O}_{2}, \mathrm{CHX}\right.$, and $\left.\mathrm{ClO}_{2}\right)$ in human PDLSCs and (ii) to monitor how the aging of PDLSC cultures affect the cellular response to the irrigative chemicals tested.

\section{Materials and methods}

\section{Antiseptic agents}

Analytically pure, aqueous solutions of $\mathrm{H}_{2} \mathrm{O}_{2}(3 \%)$ and $\mathrm{CHX}$ $(0.2 \%)$ were obtained from the Central Apotheke of the Semmelweis University. The applied concentrations of these antiseptic agents were selected according to their doses applied in the routine clinical practice in periodontology. Highpurity $\mathrm{ClO}_{2}$ (Solumium ${ }^{\mathrm{TM}}$, Solumium Ltd., Hungary) $(0.025 \%)$ was prepared by a novel membrane technology [35] at the Department of Physics, Budapest University of Technology and Economics. For periodontal treatments and oral rinse, 1:10 dilution of the abovementioned $\mathrm{ClO}_{2}$ solution is suggested in human applications.

\section{Cell isolation and cultures}

Periodontal ligament stem cells (PDLSCs) were isolated from impacted, healthy third molars of healthy young adults. Tooth extractions were carried out according to the guidelines approved by the Ethical Committee of the Hungarian Medical Research Council at the Department of Oral Diagnostics, Semmelweis University. We have obtained written consent from each patient. This study was approved by the Semmelweis University Regional and Institutional Committee of Science and Research Ethics. The numbers of the ethical permissions are as follows: 17458/2012/EKU, 25459-4/2019/EKU - ETT-TUKEB. Stem cells were isolated as we described previously [36], with some modifications. In brief, the periodontal ligament was removed by a sterile scalpel and digested in collagenase type I (Sigma Ltd., St. Louis) dissolved in Dulbecco's phosphate buffer saline (DPBS, Lonza) solution $(1 \mathrm{mg} / \mathrm{mL})$ for $1 \mathrm{~h}$ at $37{ }^{\circ} \mathrm{C}$. After that, the remaining tissue pieces were pushed through a $22-\mathrm{G}$ needle to loosen the tissue structure and gain single cell cultures. Stem cell cultures were maintained under standard conditions in the alpha modification of Eagle's medium ( $\alpha$ MEM, Gibco) supplemented with $10 \%$ fetal bovine serum (FBS, Gibco), 2 mM L-glutamine (Sigma Ltd., St.Louis, USA), 100 units/ $\mathrm{mL}$ penicillin, and $100 \mathrm{mg} / \mathrm{mL}$ streptomycin (Gibco). Subconfluent cultures were passaged weekly at a ratio 1:20 with $0.05 \%$ trypsin-EDTA (Gibco). For the experiments, cell populations from the P3 and P7 passages were used. Characterization of PDL stem cells isolated in this way was already described [36], too. The most important characteristics of these cells were (i) increased proliferative capacity, (ii) expressing STRO-1 mesenchymal stem cell marker, (iii) osteogenic differentiation, and (iv) transient deurodifferentiation.

\section{Concentration-response study}

To evaluate the concentration-dependent effects of the 3 antiseptic agents $\left(\mathrm{H}_{2} \mathrm{O}_{2}, \mathrm{CHX}\right.$, and $\left.\mathrm{ClO}_{2}\right), 9$ different dilutions of each agent were prepared with growth medium (from $3.91 \times$ $10^{-6}$ to $10^{-3} \mathrm{M}$, by $1: 2$ dilution in each step). $\mathrm{As}^{\mathrm{ClO}_{2}}$ is photosensitive and volatile, its dilution series were made in dark Eppendorf tubes which were opened only for the inevitably required time. After a 48-h-long incubation, cell viability was assessed by WST-1 test and impedimetric measurement, respectively (see below). The average inhibitory concentration $\left(\mathrm{IC}_{50}\right)$ values corresponding to the $50 \%$ viable cells or 0.5 normalized CI were determined from the concentrationeffect curves in the case of the two methods, respectively.

\section{Cell viability assays}

\section{Impedimetry}

The effect of irrigative agents on the viability of the PDLSC cells was assessed using the xCELLigence SP System (Roche Applied Science, Indianapolis, IN, USA), which monitors the cellular events by measuring electrical impedance across interdigitating gold microelectrodes integrated on the bottom of tissue culture plates (E-plates). The detected impedance is influenced by the viability and morphology of the attached cells on the surface of the electrodes. The presence of cells due to their insulating plasma membranes constrain the electrical current and lead to an increase in the electrode impedance. The impedance depends on the number of the attached cells and on the dimensional change of the attached cells on the electrodes. More cells attached to the electrode or spreading cause a larger increase in the impedance. The change in impedances represented as "cell index" (CI) which is a relative and dimensionless value. Briefly, the experimental protocol was as follows: to register the background value, $100 \mu \mathrm{L}$ of culture medium was added to each well and impedance was recorded for $1 \mathrm{~h}$ to gain constant background curves of impedance. In the following step, PDLSCs were seeded in $10^{5}$ cells $/ \mathrm{mL}$ density. After $24-\mathrm{h}$ incubation, they were treated with the solutions of the investigated irrigative compounds 
$\left(\mathrm{H}_{2} \mathrm{O}_{2}, \mathrm{CHX}\right.$, and $\left.\mathrm{ClO}_{2}\right)$ for $10 \mathrm{~min}$ and the medium served as reference. The viability of the PDLSC was monitored for $96 \mathrm{~h}$. Normalized impedance to the control calculated by the integrated software (RTCA 1.2-Roche Applied Science, Indianapolis, IN, USA) was used for the statistical evaluation. Each data point represents the mathematical average of three parallels.

\section{WST-1 assay}

This assay is dedicated to measuring the viability of PDLSCs [37]. In 96-well culture plates, 10,000 PDLSCs were seeded. After $24 \mathrm{~h}$, samples were treated with the irrigative compounds, and final concentrations were $\mathrm{H}_{2} \mathrm{O}_{2} 0.3 \%$, CHX $0.02 \%$, and $\mathrm{ClO}_{2} 0.0025 \%$ and $0.00025 \%$ solutions in $4-4$ parallel wells. After $10 \mathrm{~min}$, all the irrigative agents were removed and the samples were washed three times with normal growth medium, simulating the diluting effect of saliva in the oral cavity during the periodontal treatments. Forty-eight hours after the treatments, the cell viability was measured by the cell proliferation reagent containing water-soluble tetrazolium salt, WST-1 [2-(4-Iodophenyl)-3-(4-nitrophenyl)-5-(2,4disulfophenyl)-2H-tetrazolium] (Roche). This assay determines mitochondrial dehydrogenase enzyme activity resulting water-soluble cleavage product. The WST-1 reagent was used at $1: 20$ dilution and incubation time was $2 \mathrm{~h}$ at $37{ }^{\circ} \mathrm{C}$. Absorbance was measured at $450 \mathrm{~nm}$ with a reference wavelength of $655 \mathrm{~nm}$ by a microplate reader (BIO-RAD Model 3550). Background control values were determined in wells seeded with no cells. Each value represents the average of minimum 3 parallel measurements.

\section{Morphological studies}

Cellular morphology was observed under an inverted phasecontrast microscope (Nikon TMS). Photomicrographs were taken applying a high-performance CCD camera (COHU) and the Scion image software.

\section{Immunocytochemistry}

PDLSC cultures grown in 8 chamber slides (Nunc Lab-Tek) were treated with the antiseptic agents similar to the viability studies. After $48 \mathrm{~h}$, treated and untreated cell cultures were fixed in 4\% PFA in PBS for 20 min at room temperature (RT). To block non-specific binding, $5 \%$ goat serum in PBS was applied for $1 \mathrm{~h}$ at RT. Then cell cultures were incubated with the primary antibodies diluted 1:100 with $2.5 \%$ goat serum in PBS overnight at $4{ }^{\circ} \mathrm{C}$. The applied primary antibodies were the following: anti-STRO-1 antibody (type mouse $\operatorname{IgM}$ ) - a generous gift from Prof. Richard Oreffo (University of Southampton, UK); anti-CD90 (Thy-1; type mouse IgG) and the anti-CD105 (endoglin; type mouse IgM) antibodies purchased from Calbiochem and Santa Cruz Biotechnology, respectively. Goat anti-mouse IgM and IgG type secondary antibodies conjugated with Alexa Fluor 488 (Molecular Probes) were diluted with $2.5 \%$ goat serum in PBS in 1:2000 and 1:1000 respectively. The incubation time was $60 \mathrm{~min}$ at RT. Finally, the walls of the chambers were removed and the slides were mounted with ProLong Gold antifade reagent with DAPI (Molecular Probes). Immunocytochemically labeled cell cultures were investigated under a fluorescence microscope (Nikon Eclipse E600), the photos were taken by a Retiga 2000R digital CCD camera (QImaging), and analyzed by the Image Pro software (Media Cybernetics). Free macros for automated fluorescence analysis of image processing software FIJI/ImageJ were applied to evaluate immunostaining of stem cell markers. Each test point represents $3 \times 3$ reading of the samples.

\section{Statistical evaluation of data}

Data are expressed as the arithmetical means \pm standard errors of the mean (SEM) from minimum 3 independent experiments with 3-6 parallels. Statistical evaluation of the data was performed by the STATISTICA 10 software applying Kruskal-Wallis test (the non-parametric analog of the ANOVA). A difference was considered statistically significant if $P<0.05$.

\section{Results}

\section{Time-course effects}

The impedimetric analysis is a dedicated technique to register small differences in cell density in a real-time system. Due to the high sensitivity of the assay, we could evaluate short- and long-term effects elicited by the three antiseptic agents $\left(\mathrm{H}_{2} \mathrm{O}_{2}\right.$, $\mathrm{CHX}$, and $\mathrm{ClO}_{2}$ ) (Fig. 1). In short-term (0-2 h) detection (Fig. 1a), a rapid decrease of normalized $\mathrm{CI}$ profile was recorded in $0.3 \% \mathrm{H}_{2} \mathrm{O}_{2}$ and $0.02 \%$ CHX treatments which effects were identical to strong surface membrane level cytotoxic effects resulting loss in electrical insulating capacity. High and low concentrations $(0.0025 \%$ and $0.00025 \%)$ of $\mathrm{ClO}_{2}$ worked differently; however, a decrease of normalized CI was still observed, but this compound was significantly less toxic compared to the other two antiseptic substances. In long-term relations (2-120 h) (Fig. 1b), treatments with $0.3 \% \mathrm{H}_{2} \mathrm{O}_{2}$ and $0.02 \%$ CHX retained their short-term cytotoxic effects, while the characteristics of curves in samples treated with $0.00025 \%$ and $0.0025 \% \mathrm{ClO}_{2}$ differed as a consistent increase of the curves $(0.00025 \%-30 \mathrm{~h} ; 0.0025 \%-50 \mathrm{~h})$ was detected, which points out the presence of a surviving and proliferating subpopulation of cells. 


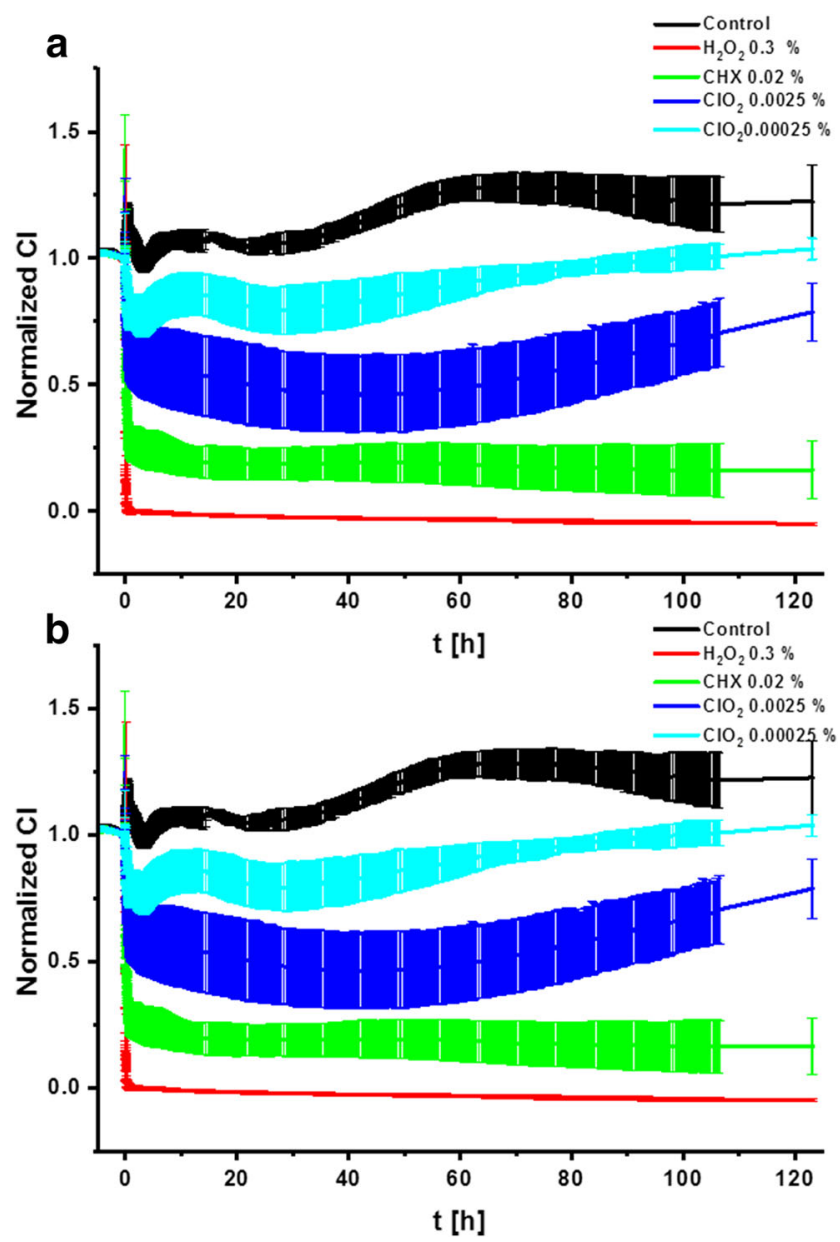

Fig. 1 The curves of the normalized cell index (CI) value represent the short- and long-term effects of the irrigative agents on PDLSCs recorded by impedimetric analysis. Short-term (2 h) (a) and long-term (120 h) (b) toxic effects of $\mathrm{H}_{2} \mathrm{O}_{2}$ (red), $\mathrm{CHX}$ (green), and $\mathrm{ClO}_{2}$ (blue and light blue) on PDLSCs applied at $0.1 \times$ concentrations used in clinical routine $(0.3 \%$, $0.02 \%$, and $0.0025 \%$ or $0.00025 \%$ )

\section{Concentration-response study}

The concentration dependence of the cytotoxic effects was evaluated in two independent assays: (i) WST-1 detects viability of cells on the basis of mitochondrial-dehydrogenase activity and (ii) impedimetrics evaluate the number of living cells on the basis of electrical insulator ability of the surface membrane. The concentration range study showed that the two assays which are based on independent cellular mechanisms led to remarkably overlapping results (Fig. 2a, b). Ranking of the threshold concentration sensitivity of PDLSCs to of irrigative compounds showed the following order of sensitivity: $\mathrm{CHX}>>\mathrm{H}_{2} \mathrm{O}_{2}>\mathrm{ClO}_{2}$. The calculated $\mathrm{IC}_{50}$ values related to the highest concentration applied in periodontology are presented in Table 1 . The $\mathrm{IC}_{50}$ were well comparable in the two different assays applied: (i) WST-1 test: $\mathrm{IC}_{50}(\mathrm{CHX})=29.5 \mu \mathrm{M}<\mathrm{IC}_{50}\left(\mathrm{H}_{2} \mathrm{O}_{2}\right)=209 \mu \mathrm{M}<\mathrm{IC}_{50}$ $\left(\mathrm{ClO}_{2}\right)=638 \mu \mathrm{M}$; (ii) impedimetry: $\mathrm{IC}_{50}(\mathrm{CHX})=36.4 \mu \mathrm{M}$
$<\mathrm{IC}_{50}\left(\mathrm{H}_{2} \mathrm{O}_{2}\right)=327 \mu \mathrm{M}<\mathrm{IC}_{50}\left(\mathrm{ClO}_{2}\right)=795 \mu \mathrm{M}$. Calculating proportions from the appropriate pair of concentrations (clinically applied concentration/ $/ \mathrm{IC}_{50}$ ) shows that $\mathrm{ClO}_{2}$ - compared to $\mathrm{H}_{2} \mathrm{O}_{2}$ and $\mathrm{CHX}$ - has the most advantageous ratio. The concentration applied in dental praxis is a 4.7to 5.8 -fold of the $\mathrm{IC}_{50}$ determined by different assays in the present experiment.

\section{Morphology/viability studies}

In cellular targets during dental treatments, the changing sensitivity of cells might be a major limiting factor. The PDLSC cultures were investigated under a phase-contrast microscope $48 \mathrm{~h}$ after treatments with $0.3 \% \mathrm{H}_{2} \mathrm{O}_{2}, 0.02 \% \mathrm{CHX}, 0.0025 \%$ $\mathrm{ClO}_{2}$, or $0.00025 \% \mathrm{ClO}_{2}$. Our morphological observations are in line with the abovementioned data. The untreated cell cultures (Fig. 3a) demonstrate healthy fibroblast-like morphology. The deteriorating effects of $\mathrm{CHX}$ and $\mathrm{H}_{2} \mathrm{O}_{2}$ were well detectable (Fig. 3b, c). The number of cells dramatically decreased in response to these treatments and the originally spindle-shaped cells become more rounded and their processes get much thinner. These observations collectively indicate a drastic decline in cell viability. In contrast, $\mathrm{ClO}_{2}$ did not provoke morphological changes compared to the control group (Fig. 3d, e).

In WST-1 assay and impedimetry, $\mathrm{H}_{2} \mathrm{O}_{2}$ elicited the strongest cytotoxic effect, resulting in a complete lack of any viable cells in both P3 and P7 samples. Application of CHX also resulted in significantly deteriorating effects on the viability of PDLSC cultures of both generations (Fig. 4). The lower concentration of $\mathrm{ClO}_{2}$ was unequivocally neutral in $\mathrm{P} 3$ and P7 cells in both WST-1 and impedimetry assays. The higher applied concentration of $\mathrm{ClO}_{2}$ seemed to have no effect only in the WST-1 test, but it showed a significant inhibitory effect in the P3 PDLSC samples by impedimetry (Fig. 4b).

In stem cell marker tests, the expression of three mesenchymal stem cell markers (STRO-1, CD90, and CD105) were assayed as a reference to find out whether the application of the irrigative compounds has any influence on the stem cell characteristics of PDLSCs in different passage levels (P3 and P7).

Our indirect immunocytochemistry-based evaluations show that none of the tested chemicals provoked characteristic changes in the expression of the aforementioned stem cell markers either in $\mathrm{P} 3$ or in $\mathrm{P} 7$ generation of the PDLSC cultures. Around 50\% of the cells are STRO-1-positive and near $100 \%$ of the cells express the CD90 and CD105 markers both in control and treated groups (Fig. 5). Quantitative evaluations of immunocytochemistry (Table 2) in the treated PDLSC cultures show that the CHX treatment resulted in an increased expression of all the 3 stem cell markers (CD105 > CD90 >> STRO-1) in P3 cells while in P7 cells, the CHX treatment resulted a significant decrease in the expression of all the 3 

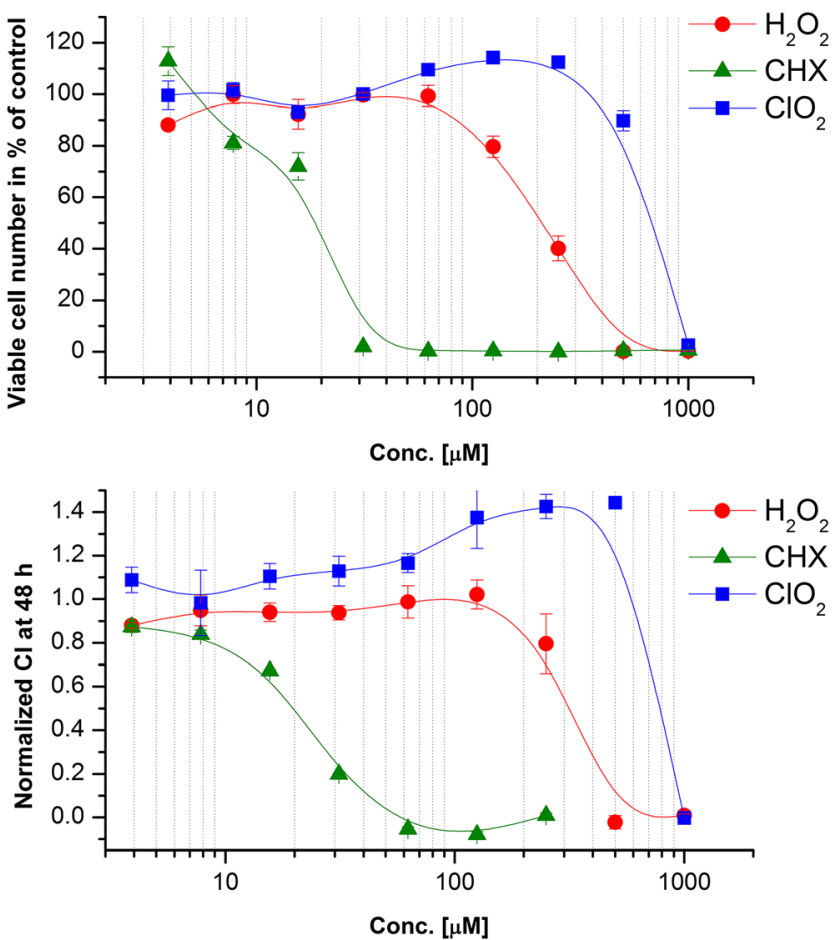

Fig. 2 Dose-response curves of PDLSCs treated with irrigative agents: $\mathrm{H}_{2} \mathrm{O}_{2}, \mathrm{CHX}$, and $\mathrm{ClO}_{2}$. Analysis of 48-h cultures by a WST-1 test and $\mathbf{b}$ impedimetric analysis

stem cell markers compared to the expression on P3 cells. In P3 cells, the applied $\mathrm{ClO}_{2}$ concentrations (1/1 and 1/10) caused a significant increase in the markers STRO-1 and CD105, while in CD90, this effect was observed only at the lower (1/10) concentration. In contrast, in P7 cells, a significant decrease of the markers was observed compared to P3 cells (except CD90 where $\mathrm{ClO}_{2} 1 / 1$ resulted in a control level expression of the marker).

\section{Discussion}

There is a wide variety of irrigative agents applied as active ingredients of mouthwashes (e.g., NaF, CPC, xylitol, volatile oil extracts). Nevertheless, $\mathrm{H}_{2} \mathrm{O}_{2}$ and $\mathrm{CHX}$ are

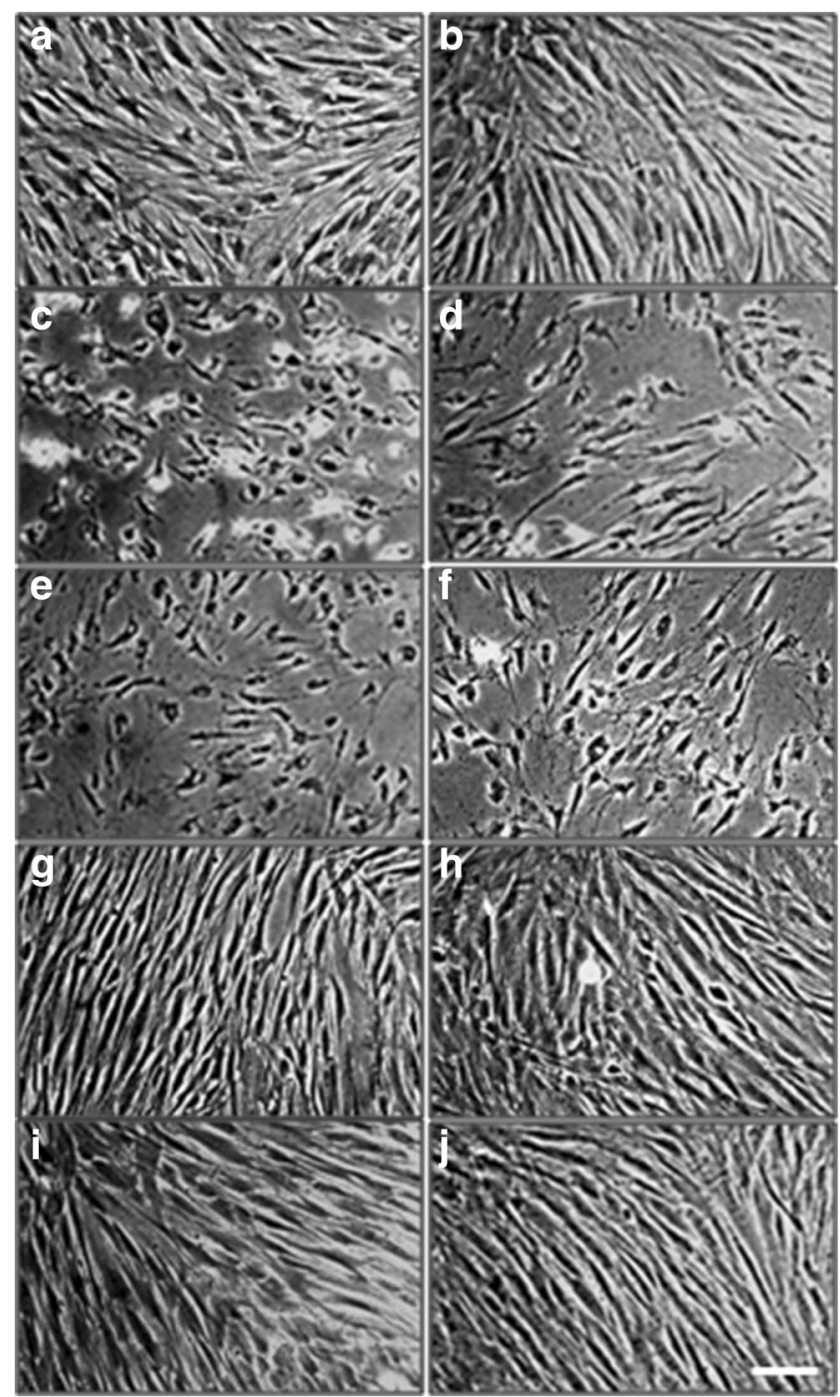

Fig. 3 Phase contrast microscopical study of PDLSC cultures from passage $3(\mathbf{a}, \mathbf{c}, \mathbf{e}, \mathbf{g}, \mathbf{i})$ and passage $7(\mathbf{b}, \mathbf{d}, \mathbf{f}, \mathbf{h}, \mathbf{j})$. Changes in morphology compared to the untreated control $(\mathbf{a}, \mathbf{b})$ were evaluated $48 \mathrm{~h}$ after the treatment with 0.3 $\% \mathrm{H}_{2} \mathrm{O}_{2}(\mathbf{c}, \mathbf{d}), 0.02 \% \mathrm{CHX}(\mathbf{e}, \mathbf{f}), 0.0025 \% \mathrm{ClO}_{2}(\mathbf{g}, \mathbf{h})$, and $0.00025 \%$ $\mathrm{ClO}_{2}(\mathbf{i}, \mathbf{j})$. All photomicrographs were taken at the same magnification. Bar indicates $100 \mu \mathrm{m}$

Table 1 The calculated $\mathrm{IC}_{50}$ values of the irrigative compounds tested and their clinically applied concentrations in periodontology

\begin{tabular}{|c|c|c|c|c|c|c|}
\hline \multirow[t]{3}{*}{ Compound } & \multicolumn{2}{|l|}{ In vitro } & \multicolumn{2}{|c|}{ Clinical } & \multirow[t]{3}{*}{ Clinical/IC $\mathrm{C}_{50}$ WST-1 test } & \multirow[t]{3}{*}{ Clinical $/ \mathrm{IC}_{50}$ impedimetry } \\
\hline & \multirow[t]{2}{*}{$\mathrm{IC}_{50}$ WST-1 test $(\mu \mathrm{M})$} & \multirow[t]{2}{*}{$\mathrm{IC}_{50}$ impedimetry $(\mu \mathrm{M})$} & \multicolumn{2}{|c|}{$\begin{array}{l}\text { Applied concentration in } \\
\text { periodontology }\end{array}$} & & \\
\hline & & & $\%$ & $\mu \mathrm{M}$ & & \\
\hline $\mathrm{H}_{2} \mathrm{O}_{2}$ & 209 & 327 & 3.5 & 88,240 & 422 & 269 \\
\hline $\mathrm{CHX}$ & 16.6 & 20.5 & 0.25 & 3960 & 238.5 & 193 \\
\hline $\mathrm{ClO}_{2}$ & 638 & 795 & 0.025 & 3700 & 5.8 & 4.65 \\
\hline
\end{tabular}

The efficacy of the compounds can be estimated by the ratio of clinically applied, curative concentration/ $/ \mathrm{IC}_{50}$ 
a

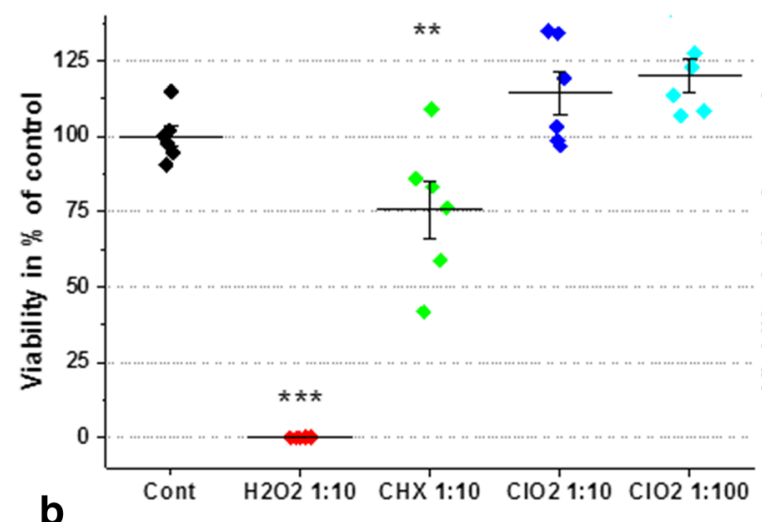

b

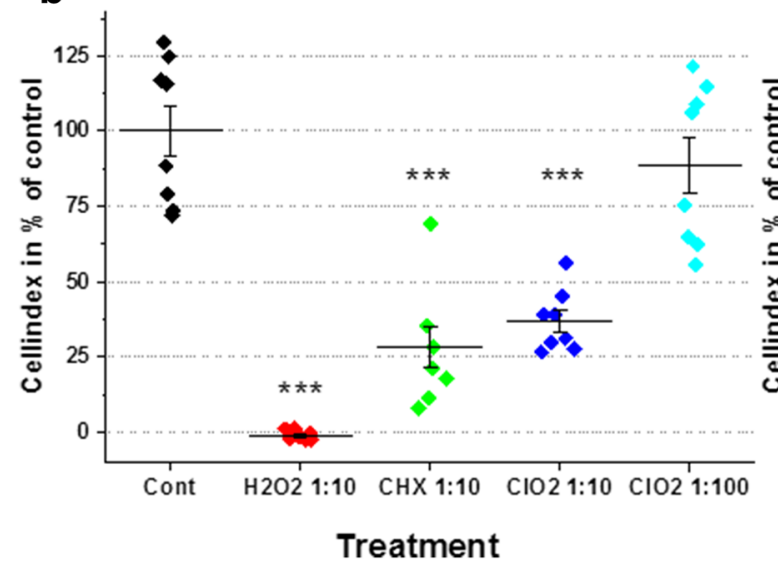

Fig. 4 The viability of the PDLSC cultures from passage $3(\mathbf{a}, \mathbf{b})$ and passage $7(\mathbf{c}, \mathbf{d})$ after 48 -h treatment with irrigative agents $\left(\mathrm{H}_{2} \mathrm{O}_{2}\right.$ 1:10 = $0.3 \% \mathrm{H}_{2} \mathrm{O}_{2}$; CHX 1:10 $=0.02 \% \mathrm{CHX} ; \mathrm{ClO}_{2} 1: 10=0.0025 \% \mathrm{ClO}_{2}$ and
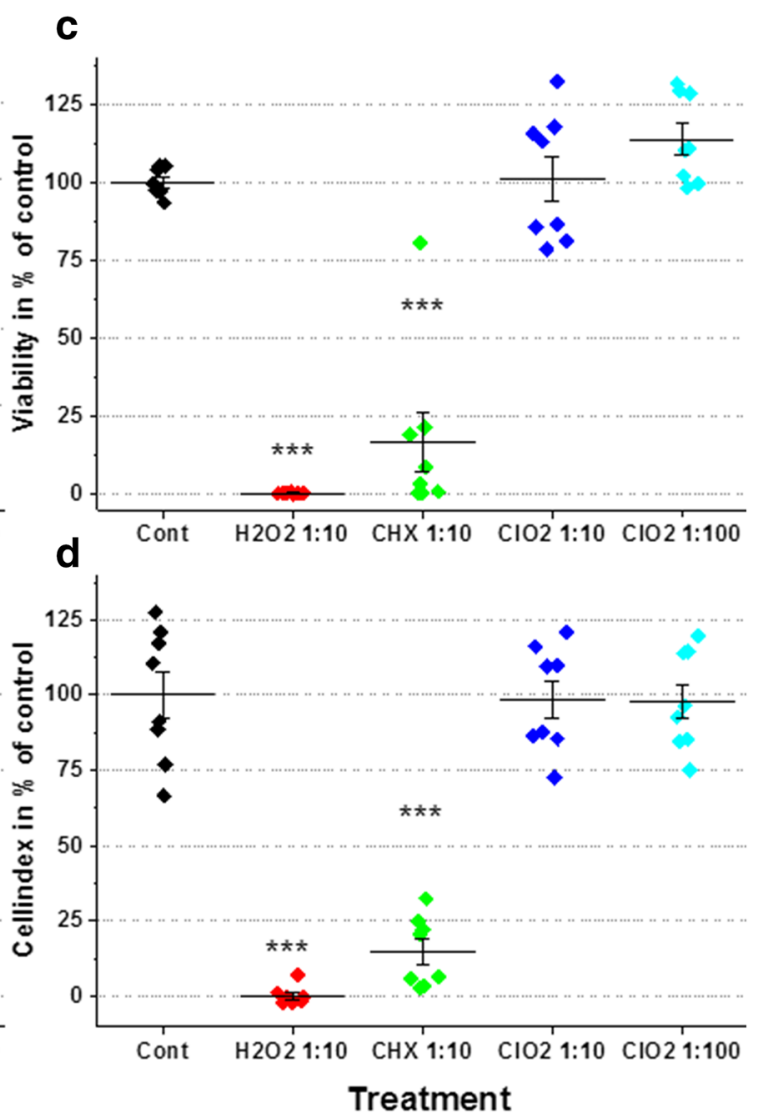

$\mathrm{ClO}_{2} 1: 100=0.00025 \% \mathrm{ClO}_{2}$ ). The cell numbers were assayed by WST1 test $(\mathbf{a}, \mathbf{c})$ and by impedimetry $(\mathbf{b}, \mathbf{d})$; the values $( \pm \mathrm{SD})$ are expressed in $\%$ of the untreated controls. $(* * p<0.01 ; * * * p<0.001)$

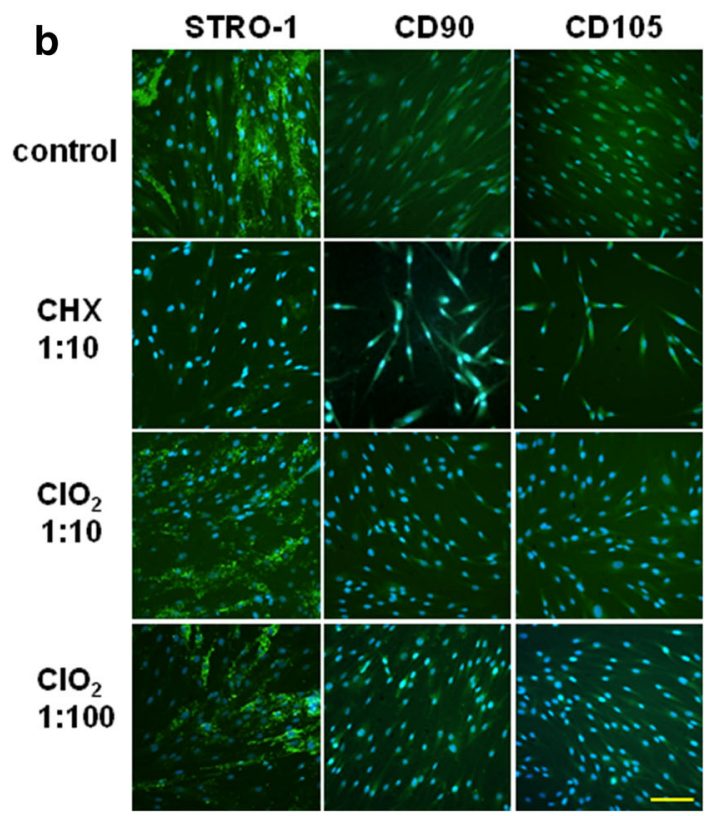

not be fixed for immunocytochemistry as all the cells were dead and detached from the slide.) All the photomicrographs were taken at the same magnification — bar indicates $100 \mu \mathrm{m}$
Fig. 5 Immunofluorescent detection of the mesenchymal stem cell markers STRO-1, CD90, and CD105 in control (a) and PDLSC (b) cultures $48 \mathrm{~h}$ after the treatment with irrigative agents CHX $(0.02 \%)$ and $\mathrm{ClO}_{2}(0.0025$ or $0.00025 \%)$. (The cultures treated with $\mathrm{H}_{2} \mathrm{O}_{2}$ could 
Table 2 Effect of treatment with $0.02 \%$ chlorhexidine (CHX), $0.0025 \%(1 / 1)$, or $0.00025 \%$ (1/10) $\mathrm{ClO}_{2}$ on the expression of stem cell markers of PDL stem cells in passage $3(\mathrm{P} 3)$ and passage 7 (P7)

\begin{tabular}{|c|c|c|c|c|c|}
\hline \multirow[t]{3}{*}{ Stem cell marker } & \multirow[t]{3}{*}{ Treatment } & \multicolumn{2}{|l|}{ P3 } & \multicolumn{2}{|l|}{$\mathrm{P} 7$} \\
\hline & & Fluo. int. [\%] & $\pm \mathrm{SD}$ & Fluo. int. [\%] & $\pm \mathrm{SD}$ \\
\hline & & Control $=100 \%$ & & Control $=100 \%$ & \\
\hline \multirow[t]{3}{*}{ STRO-1 } & $\mathrm{CHX}$ & $130.52 *$ & 6.55 & 86.02 & 4.15 \\
\hline & $\mathrm{ClO}_{2}(1 / 1)$ & $216.52 * * *$ & 10.12 & $120.43^{*}$ & 3.32 \\
\hline & $\mathrm{ClO}_{2}(1 / 10)$ & $145.78 * *$ & 5.55 & 114.69 & 5.41 \\
\hline \multirow[t]{3}{*}{ CD90 } & $\mathrm{CHX}$ & $199.23 * * *$ & 7.32 & $30.98 * * *$ & 3.71 \\
\hline & $\mathrm{ClO}_{2}(1 / 1)$ & 83.07 & 4.44 & 97.74 & 4.02 \\
\hline & $\mathrm{ClO}_{2}(1 / 10)$ & $159.23 * *$ & 5.11 & $54.92 * * *$ & 4.31 \\
\hline \multirow[t]{3}{*}{ CD105 } & $\mathrm{CHX}$ & $218.18^{* * *}$ & 9.71 & 104.81 & 6.09 \\
\hline & $\mathrm{ClO}_{2}(1 / 1)$ & $213.90 * * *$ & 12.10 & $55.46^{* * *}$ & 3.92 \\
\hline & $\mathrm{ClO}_{2}(1 / 10)$ & $127.80^{*}$ & 3.22 & $15.74 * * *$ & 2.76 \\
\hline
\end{tabular}

$* p<0.05 ; * * p<0.01 ; * * * p<0.001$ considered to be the most frequently used components due to their strong antiseptic, analgesic, and anti-inflammatory effect in the oral cavity.

The strong oxidant $\mathrm{H}_{2} \mathrm{O}_{2}$ is applied in dentistry because of its advantageous whitening, disinfectant, and hemostatic properties. Its mechanism of action is based on the $\mathrm{H}_{2} \mathrm{O}_{2}$ penetration into the target cell where its generated oxygen radicals destroy the cell lipids and proteins of the membranes as well as the DNA in the nucleus. Also, in low concentrations, $\mathrm{H}_{2} \mathrm{O}_{2}$ has apoptotic effects. It was considered as a wide range antimicrobial substance; however, its effective concentration range is much higher than that of CHX as its effectiveness is reduced in Gram-positive bacteria by catalase activity [38]. Therefore, their in vitro sporicide effects are evident only in really high (10-30\%) concentrations when the incubation time is long [38]. According to the recent regulations of the European Union, only low concentrations of $\mathrm{H}_{2} \mathrm{O}_{2}$ are approved for human use as its wound-healing inhibitory and scarring effects were detected. For tooth whitening, at present, the maximal approved dose is $6 \%$ in Europe [39].

CHX is applied as salts of chlorohexidine, and its most frequently used derivative is chlorohexidine-di-glyconate. The positively charged CHX molecules have high affinity to the negatively charged molecular targets such as surface membrane and bacterial cell wall, thereby disturbing their integrity and resulting in bacterial cell lysis [22]. An additional advantageous property of CHX is that it adheres to both hard and soft oral tissues, which results in prolonged effects. The instant and sustained bactericide and bacteriostatic effects of CHX inhibit the development of biofilm and also help to remove the already persisting one. The adverse side effect of $\mathrm{CHX}$ is that the precipitation of proteins of the ruined bacteria provoke discoloration of teeth [22].

$\mathrm{ClO}_{2}$ has been applied in dental offices for many years for sterilization of the air [18] or dental instruments [19]. However, the direct use of $\mathrm{ClO}_{2}$ for human oral treatments was limited since the purity level of the available preparations had been rather low. Additionally, this volatile molecule could not be preserved for long term as the concentration of reactive oxygen radicals drops relatively fast after application [35]. Moreover, the conventional manufacturing process of $\mathrm{ClO}_{2}$ is accompanied by the formation of toxic by-products. All of these problems have been solved by a novel membrane filtration technology, which resulted in a product, Solumium ${ }^{\mathrm{TM}}$, containing an only highly pure and stable form of $\mathrm{ClO}_{2}$ that also has longer stability compared to previously produced unpurified compounds [35]. As a result, the effective local concentration of $\mathrm{ClO}_{2}$ can be sustained over a long period of time.

A major message of the present work is the high concentration difference in which $\mathrm{ClO}_{2}$ exerts its toxic effects on human PLD-derived cells and microbes. The exact reason(s) for this is (are) not known but the parallel existence of several mechanisms can be regarded.

(i) Free radicals reach the molecular or cellular targets by size-limited diffusion [35].

(ii) The radicals targeting to proteins of membranes and cytoplasm are acting selectively on cysteine, methionine, tryptophan, and tyrosine residues [40].

(iii) Reactions with $\mathrm{Fe}^{2+}$ and $\mathrm{Mn}^{2+}$ ions or glutathione also limit its effect [40-43].

(iv) The cytotoxic effects of $\mathrm{ClO}_{2}$ may appear only in the size range of microbes, but not in eukaryote cells. In microbes, the low amount of cell surface proteins limits the neutralization of $\mathrm{ClO}_{2}$ molecules, while the significantly bigger eukaryotic cells are only superficially damaged [35].

(v) Furthermore, in some fields of application where tissues cannot be directly reached, for example, in dentistry, it is also essential that $\mathrm{ClO}_{2}$ can transform to gaseous state so 
that it can easily penetrate into complex structures such as the biofilm or the dentin in periodontal treatment or root canal disinfection, respectively [33, 34].

(vi) In contrast to antibiotics, a special advantage of the $\mathrm{ClO}_{2}$ application is that it acts through mechanisms for which the microorganisms cannot develop resistance in a classical sense [35].

In the present study, we compared the cytotoxic effects of the hyperpure $\mathrm{ClO}_{2}$, manufactured by new semipermeable membrane technology, with the effects of $\mathrm{H}_{2} \mathrm{O}_{2}$ and $\mathrm{CHX}$, which are routinely applied in periodontal treatments and mouthwashes. The influence of the abovementioned three antiseptics on PDLSC cultures was evaluated by several cell biological methods. According to our impedimetric results, $\mathrm{H}_{2} \mathrm{O}_{2}$ has the strongest and fastest cytotoxic effect as it killed all the cells within $1 \mathrm{~min}$. CHX caused moderate and somewhat slower cell death killing $50 \%$ of the cells in 5 min and about $70 \%$ during the first half an hour. On the contrary, $\mathrm{ClO}_{2}$ exhibited the slightest cytotoxic effect killing only 20-30\% of the cells (depending on the concentration applied) during the first $30 \mathrm{~min}$ of direct exposure (Fig. 1a). The long-term impedimetric analyses revealed that after $\mathrm{ClO}_{2}$ treatment, the proliferation of the remaining cell population can compensate cell loss, indicating that the negative action of this antiseptic agent was temporary. Nevertheless, after CHX treatment, no sign of repopulation was observed during the 5-day-long period, referring to that these cell cultures lost their regeneration potential permanently (Fig. 1b).

In agreement with the impedimetric analysis, our morphological study also proved that $\mathrm{H}_{2} \mathrm{O}_{2}$ and $\mathrm{CHX}$ have stronger cytotoxic effects on PDLSC cultures than $\mathrm{ClO}_{2}$. We observed on the microphotographs that $\mathrm{H}_{2} \mathrm{O}_{2}$ and $\mathrm{CHX}$ treatments led to large-scale cell death whereas the cell could retain their healthy, fibroblast-like morphology after $\mathrm{ClO}_{2}$ treatment. The WST-1 viability assay confirmed the previous results showing complete and moderate loss of viable cells after $\mathrm{H}_{2} \mathrm{O}_{2}$ and $\mathrm{CHX}$ treatments, respectively, but no change in viability 2 days after $\mathrm{ClO}_{2}$ treatment. By qualitative and quantitative evaluation of immunohistochemistry demonstrated that application of $\mathrm{CHX}$ and $\mathrm{ClO}_{2}$ results in increased expression of the three stem cell markers (STRO-1, CD90, and CD105), nevertheless, the concentration dependence of the process is more fine-tuned in $\mathrm{ClO}_{2}$, while effect of $\mathrm{CHX}$ seems to be coarsely controlled.

Many papers reported the strong cytotoxic effects of $\mathrm{CHX}$ and $\mathrm{H}_{2} \mathrm{O}_{2}$ (e.g., low $\mathrm{IC}_{50}$ values) in the concentration ranges of clinical applications even on the non-target, healthy cells of the patient [20, 21, 23-25, 44]. Our present data obtained by WST-1 test and impedimetry provide evidence for these harmful effects even on PDLSC (Fig. 2). However, the novel hyperpure preparation $\mathrm{ClO}_{2}$ has only a very weak toxic effect on oral/dental cells (oral epithelium), in spite of its antimicrobial effects reported previously [35]. Studying the direct antibacterial and the biofilm-dissolving effects of $\mathrm{CHX}$ and $\mathrm{ClO}_{2}$, the group of one of us found that approximately 10 times lower concentration of $\mathrm{ClO}_{2}$ is needed to evoke the same or even stronger effect than that of $\mathrm{CHX}$ $[33,34]$. Similarly, the concentration suggested for oral disinfectant applications is $0.02 \%$ for $\mathrm{ClO}_{2}$ and $0.2 \%$ for $\mathrm{CHX}$ [45]. Very importantly, on PDLSCs, the cytotoxic potency difference between $\mathrm{CHX}$ and $\mathrm{ClO}_{2}$ turns to the reverse and overshoots: the viability assay yielded an $\sim 21$ times higher $\mathrm{IC}_{50}$ concentration for $\mathrm{ClO}_{2}$ compared to $\mathrm{CHX}$. Thus, $\mathrm{ClO}_{2}$ is 10 times more potent killing bacteria than $\mathrm{CHX}$ but 21 times less potent to kill human PDL cells providing an approximately 200 times gap between the two compounds when their selectivity is regarded. This fact should give a great advantage to $\mathrm{ClO}_{2}$ over $\mathrm{CHX}$ and other traditionally used disinfectant compounds in human oral applications.

Genotoxicity of traditional disinfectants used in dentistry is well known from several prior studies [46-48]. Some experiments performed on the $\mathrm{ClO}_{2}$ have also proved potential genotoxicity on buccal epithel; however, these studies evaluated the $\mathrm{ClO}_{2}$ only as a component of a complex mouth rinse where additive and synergistic effects of more active ingredients can be assumed rightly. In these studies, the alcohol consumption habits of the patients were not recorded even [29].

These characteristics of the $\mathrm{ClO}_{2}$ seem to be advantageous for dental application. Additionally, with respect to the clinical outcome, it is important to preserve dental stem cells during the interventions in order to achieve normal healing. Thus, $\mathrm{ClO}_{2}$ could be applied for various purposes such as an effective disinfectant acting on different components (e.g., Streptococcus mutans, Lactobacillus acidophilus, Enterococcus faecalis, or Candida albicans) of dental biofilm $[34,49]$ and acting on endodontium as the irrigative substance of root canal [45]. In the case of root canal biofilms containing mostly anaerobic bacteria, the antibacterial effectiveness of $\mathrm{ClO}_{2}$ was similar or lower compared to other, widely used irrigating substances like $\mathrm{CHX}$ or $\mathrm{NaOCl}$ [50] but here the $\mathrm{ClO}_{2}$ loss due to its volatility was supposedly not taken into account. According to Tanner [51], however, $\mathrm{ClO}_{2}$ is more effective against planktonic bacteria than other disinfectants (except ozone). Moreover, $\mathrm{ClO}_{2}$ is a very selective antibacterial agent (reacts only with few amino acids) and can penetrate lipid membranes more easily than other antimicrobials like $\mathrm{HOCl}$ for example [35]. As a consequence, chlorine dioxide should be more effective against biofilms than any other disinfectants.

The aging of the PDLSC cultures (passage numbers) and sensitivity to the tested substances showed a substancespecific correlation in both WST-1 test and impedimetry analysis. The passage number-independent and absolute toxic effect of $\mathrm{H}_{2} \mathrm{O}_{2}$ was manifested in the disintegration of structural elements, presumably induced by the activation of the 
corresponding key role signaling pathway of RANK ligand and by the direct free radical activity of $\mathrm{H}_{2} \mathrm{O}_{2}$ [23]. The sensitivity to CHX showed a more marked and passage numberrelated correlation which was reflected in the measured intracellular mitochondrial enzyme activities. In the case of $\mathrm{ClO}_{2}$ application, unlike the previously described two compounds, reference enzyme activities were similar to that of control in case of both passage numbers. In such conditions, $\mathrm{ClO}_{2}$ is supposed to have a gentle and transient effect, which could be easily tolerated by PDLSCs. The hyperpure $\mathrm{ClO}_{2}$ was found to be much less toxic than $\mathrm{CHX}$ or $\mathrm{H}_{2} \mathrm{O}_{2}$ and the PDLS cells were able to regenerate after hyperpure $\mathrm{ClO}_{2}$ treatment in opposite to $\mathrm{CHX}$ or $\mathrm{H}_{2} \mathrm{O}_{2}$. In accordance with this, the expression of stem cell markers was not significantly altered in the PDSC cultures.

\section{Conclusions}

In conclusion, in the present study, impedimetry was successfully applied to register cell physiological activities of PDLSCs in a real-time mode. Our studies on cell viability demonstrated that $\mathrm{ClO}_{2}$ has no significant effect on the viability of PDLSCs in concentrations that are toxic for microbes and applied in dental clinical practice. That high selectivity of $\mathrm{ClO}_{2}$ killing the microbes while not hurting the much larger stem cells is due mostly to the size-selective property of $\mathrm{ClO}_{2}$. The killing time of a cell or a biofilm is proportional with the square of its characteristic dimension (Supplementary material).

Aging of PDLSC cultures had no significant effect on the responsiveness of cultures to antimicrobial agents tested either in cell survival or in the expression of the mesenchymal stem cell markers. The active ingredients of mouthwash (e.g., $\mathrm{H}_{2} \mathrm{O}_{2}$ and $\mathrm{CHX}$ ) applied in the clinical routine for the endodontal or periodontitis management had a toxic effect on PDLSCs. On the contrary, the novel, hyperpure compound, $\mathrm{ClO}_{2}$ proved to be less toxic and the PDLSCs were able to regenerate after the treatment. Consequently, the hyperpure $\mathrm{ClO}_{2}$ seems to be an ideal compound and a superior substituent of the traditional antiseptic agents in the home and clinical dental care.

Acknowledgments The authors would like to thank Mrs. Andrea Kovács and for her technical support.

Funding Open access funding provided by Semmelweis University. This project was supported by NKFIH awards K112364 (Dr. Lohinai, Zs.; Hungarian Scientific Research Development \& Innovation Office) and EFOP-3.6.2-16-2017-00006 (Dr. S. Nagy, K. and Prof. Varga, G.; Hungarian Human Resources Development Operational Program). The study was also supported by the Hungarian Ministry of Human Capacities, Higher Education Excellence Program to Semmelweis University, Therapy Research Modul (Dr. S. Nagy, K. and Prof. Varga, G). The research was financed by the Thematic Excellence Programme
(2020-4.1.1.-TKP2020) of the Ministry for Innovation and Technology in Hungary, within the framework of the Therapy thematic programme of the Semmelweis University. (Dr.S. Nagy, K., Dr. Lohinai, Zs. and Prof. Varga, G.)

\section{Compliance with ethical standards}

Conflict of interest The authors declare that they have no conflict of interest.

Ethical approval All procedures performed in studies involving human participants were in accordance with the ethical standards of the institutional and/or national research committee and with the 1964 Helsinki declaration and its later amendments or comparable ethical standards.

Informed consent Informed consent was obtained from all individual participants included in the study.

Open Access This article is licensed under a Creative Commons Attribution 4.0 International License, which permits use, sharing, adaptation, distribution and reproduction in any medium or format, as long as you give appropriate credit to the original author(s) and the source, provide a link to the Creative Commons licence, and indicate if changes were made. The images or other third party material in this article are included in the article's Creative Commons licence, unless indicated otherwise in a credit line to the material. If material is not included in the article's Creative Commons licence and your intended use is not permitted by statutory regulation or exceeds the permitted use, you will need to obtain permission directly from the copyright holder. To view a copy of this licence, visit http://creativecommons.org/licenses/by/4.0/.

\section{References}

1. Gronthos S, Mankani M, Brahim J, Robey PG, Shi S (2000) Postnatal human dental pulp stem cells (DPSCs) in vitro and in vivo. P Natl Acad Sci USA 97(25):13625-13630. https://doi. org/10.1073/pnas.240309797

2. Miura M, Gronthos S, Zhao M, Lu B, Fisher LW, Robey PG, Shi S (2003) SHED: stem cells from human exfoliated deciduous teeth. P Natl Acad Sci USA. 100(10):5807-5812. https://doi.org/10.1073/ pnas.0937635100

3. Seo B-M, Miura M, Gronthos S, Mark Bartold P, Batouli S, Brahim J, Young M, Gehron Robey P, Wang CY, Shi S (2004) Investigation of multipotent postnatal stem cells from human periodontal ligament. Lancet. 364(9429):149-155. https://doi.org/10. 1016/S0140-6736(04)16627-0

4. Morsczeck C, Götz W, Schierholz J, Zeilhofer F, Kühn U, Möhl C, Sippel C, Hoffmann KH (2005) Isolation of precursor cells (PCs) from human dental follicle of wisdom teeth. Matrix Biol 24(2):155165. https://doi.org/10.1016/j.matbio.2004.12.004

5. Sonoyama W, Liu Y, Fang D, Yamaza T, Seo B-M, Zhang C, Liu H, Gronthos S, Wang CY, Shi S, Wang S (2006) Mesenchymal stem cell-mediated functional tooth regeneration in swine. PLoS One 1(1):e79. https://doi.org/10.1371/journal.pone.0000079

6. Dominici M, Le Blanc K, Mueller I, Slaper-Cortenbach I, Marini F, Krause D et al (2006) Minimal criteria for defining multipotent mesenchymal stromal cells. The International Society for Cellular Therapy position statement. Cytotherapy. 8(4):315-317. https:// doi.org/10.1080/14653240600855905

7. Huang GTJ, Gronthos S, Shi S (2009) Mesenchymal stem cells derived from dental tissues vs. those from other sources: their 
biology and role in regenerative medicine. J Dental Res 88(9): 792 806. https://doi.org/10.1177/0022034509340867

8. Földes A, Kádár K, Kerémi B, Gyires K, S Zádori Z, Varga G. Mesenchymal stem cells of dental origin-their potential for antiinflammatory and regenerative actions in brain and gut damage. J Curr Neuropharm 2016;14(8):914-934. doi: https://doi.org/10. 2174/1570159X14666160121115210

9. Silvério KG, Rodrigues TL, Coletta RD, Benevides L, Da Silva JS, Casati MZ et al (2010) Mesenchymal stem cell properties of periodontal ligament cells from deciduous and permanent teeth. J Periodontol 81(8):1207-1215. https://doi.org/10.1902/jop.2010. 090729

10. Simmons PJ, Torok-Storb B (1991) Identification of stromal cell precursors in human bone marrow by a novel monoclonal antibody, STRO-1. Blood. 78(1):55-62

11. Gay IC, Chen S, MacDougall M (2007) Isolation and characterization of multipotent human periodontal ligament stem cells. Orthod Craniofac Res. 10(3):149-160. https://doi.org/10.1111/j.16016343.2007.00399.x

12. Tomokiyo A, Maeda H, Fujii S, Wada N, Shima K, Akamine A (2008) Development of a multipotent clonal human periodontal ligament cell line. Differentiation. 76(4):337-347. https://doi.org/ 10.1111/j.1432-0436.2007.00233.x

13. Song M, Kim H, Choi Y, Kim K, Chung C (2012) Skeletal myogenic differentiation of human periodontal ligament stromal cells isolated from orthodontically extracted premolars. Korean J Orthod 42(5):249-254. https://doi.org/10.4041/kjod.2012.42.5.249

14. Kammerer PW, Scholz M, Baudisch M, Liese J, Wegner K, Frerich B et al (2017) Guided bone regeneration using collagen scaffolds, growth factors, and periodontal ligament stem cells for treatment of peri-implant bone defects in vivo. J Stem Cells International 2017: 9-9. https://doi.org/10.1155/2017/3548435

15. Su Y, Liu D, Liu Y, Zhang C, Wang J, Wang S (2015) Physiologic levels of endogenous hydrogen sulfide maintain the proliferation and differentiation capacity of periodontal ligament stem cells. J Periodontol 86(11):1276-1286. https://doi.org/10.1902/jop.2015. 150240

16. Iwasaki K, Komaki M, Yokoyama N, Tanaka Y, Taki A, Kimura Y, Takeda M, Oda S, Izumi Y, Morita I (2013) Periodontal ligament stem cells possess the characteristics of pericytes. J Periodontol 84(10):1425-1433. https://doi.org/10.1902/jop.2012. 120547

17. Ding G, Liu Y, Wang W, Wei F, Liu D, Fan Z, An Y, Zhang C, Wang S (2010) Allogeneic periodontal ligament stem cell therapy for periodontitis in swine. Stem Cells 28(10):1829-1838. https:// doi.org/10.1002/stem.512

18. Kuroyama I, Osato S, Nakajima S, Kubota R, Ogawa T (2010) Environmental monitoring and bactericidal efficacy of chlorine dioxide gas in a dental office. Biocontrol Sci 15(3):103-109. https:// doi.org/10.4265/bio. 15.103

19. Takao W, Hiroshi E, Takashi S, Hirofumi Y (2013) Clinical evaluation of chlorine dioxide for disinfection of dental instruments. International J Prosthodont 26(6):541-544. https://doi.org/10. 11607/ijp.3465

20. Kinomoto Y, Carnes DL, Ebisu S (2001) Cytotoxicity of intracanal bleaching agents on periodontal ligament cells in vitro. J Endodont 27(9):574-577. https://doi.org/10.1097/00004770-20010900000005

21. Pi SH, Kim SC, Kim HT, Lee HJ, Lee SK, Kim EC (2007) Defense mechanism of heme oxygenase-1 against cytotoxic and receptor activator of nuclear factor- $\mathrm{KB}$ ligand inducing effects of hydrogen peroxide in human periodontal ligament cells. J Periodontal Res 42(4):331-339. https://doi.org/10.1111/j.1600-0765.2006.00953.x

22. Jones CG. Chlorhexidine: is it still the gold standard? Periodontology 2000. 1997;15(1):55-62. doi: https://doi.org/10. 1111/j.1600-0757.1997.tb00105.x
23. Mariotti AJ, Rumpf DAH (1999) Chlorhexidine-induced changes to human gingival fibroblast collagen and non-collagen protein production. J Periodontol 70(12):1443-1448. https://doi.org/10. 1902/jop.1999.70.12.1443

24. Chang Y-C, Huang F-M, Tai K-W, Chou M-Y (2001) The effect of sodium hypochlorite and chlorhexidine on cultured human periodontal ligament cells. Oral Surg Oral Med Oral Path Oral Radiol Endod 92(4):446-450. https://doi.org/10.1067/moe.2001.116812

25. Redding WR, Booth LC (1991) Effects of chlorhexidine gluconate and chlorous acid-chlorine dioxide on equine fibroblasts and Staphylococcus aureus. Vet Surg 20(5):306-310. https://doi.org/ 10.1111/j.1532-950X.1991.tb01272.x

26. Alleyn CD, O'Neal RB, Strong SL, Scheidt MJ, Van Dyke TE, McPherson JC (1991) The effect of chlorhexidine treatment of root surfaces on the attachment of human gingival fibroblasts in vitro. J Periodontol 62(7):434-438. https://doi.org/10.1902/jop.1991.62.7. 434

27. Cline NV, Layman DL (1992) The effects of chlorhexidine on the attachment and growth of cultured human periodontal cells. J Periodontol 63(7):598-602. https://doi.org/10.1902/jop.1992.63.7. 598

28. Lubbers JR, Chauan S, Bianchine JR (1982) Controlled clinical evaluations of chlorine dioxide, chlorite and chlorate in man. Environ Health Persp 46:57-62. https://doi.org/10.1289/ehp. 824657

29. Simpson G, Miller R, Laxton G, Clements W, editors. A focus on chlorine dioxide: the "ideal" biocide. Corrosion - National Association of Corrosion Engineers Annual Conference; 1993; New Orleans NACE

30. Noszticzius Z, Balogh S, M GW, Kály-Kullai K, Megyesi M, Volford A (2008) Permeation method and apparatus for preparing fluids containing high purity chlorine dioxide (WO2008035130)

31. Noszticzius Z, Bezur L, Gerencsér Á, Holló G, Kály-Kullai K, Lawson $\mathrm{T}$, et al. How can we check the purity of an unknown chlorine dioxide product? (in Hungarian). Magyar Fogorvos. 3: $132-7$

32. Csikány C, Várnai G, Noszticzius Z (2009) Solumium DENTAL: a hyperpure chlorine dioxide solution and its application in the dental care II. (in Hungarian). Dental Hirek 5:36-38

33. Herczegh A, Gyurkovics M, Agababyan H, Ghidán Á, Lohinai Z (2013) Comparing the efficacy of hyper-pure chlorine-dioxide with other oral antiseptics on oral pathogen microorganisms and biofilm in vitro. Acta Microbiol Imm Hung. 60(3):359-373

34. Herczegh A, Ghidan Á, Friedreich D, Gyurkovics M, Bendő Z, Lohinai Z (2013) Effectiveness of a high purity chlorine dioxide solution in eliminating intracanal Enterococcus faecalis biofilm. Acta Microbiol Imm Hung 60(1):63-75

35. Noszticzius Z, Wittmann M, Kály-Kullai K, Beregvári Z, Kiss I, Rosivall L, Szegedi J (2013) Chlorine dioxide is a size-selective antimicrobial agent. PLoS One 8(11):e79157. https://doi.org/10. 1371/journal.pone.0079157

36. Kadar K, Kiraly M, Porcsalmy B, Molnar B, Racz G, Blazsek J et al (2009) Differentiation potential of stem cells from human dental origin-promise for tissue engineering. Physiol Pharmacol 60(Suppl 7):167-175

37. Nagy K, Lang O, Lang J, Perczel-Kovach K, Gyulai-Gaal S, Kadar $\mathrm{K}$ et al (2018) A novel hydrogel scaffold for periodontal ligament stem cells. J Intervent Med Appl Sci 10(3):162-170. https://doi.org/ 10.1556/1646.10.2018.21

38. Russell AD (2001) Chemical sporicidal and sporostatic agents. Disinfection, sterilization and preservation. Lippincott W, Wilkins, Philadelphia

39. Regulation (EU) No 528/2012 of the European Parliament and of the Council of 22 May 2012 concerning the making available on the market and use of biocidal products, (2012) 
40. Napolitano MJ, Green BJ, Nicoson JS, Margerum DW (2005) Chlorine dioxide oxidations of tyrosine, $\mathrm{N}$-acetyltyrosine, and dopa. Chem Res Toxicol 18(3):501-508. https://doi.org/10.1021/ tx049697i

41. Ison A, Odeh IN, Margerum DW (2006) Kinetics and mechanisms of chlorine dioxide and chlorite oxidations of cysteine and glutathione. Inorg Chem 45(21):8768-8775. https://doi.org/10.1021/ ic0609554

42. Stewart DJ, Napolitano MJ, Bakhmutova-Albert EV, Margerum DW (2008) Kinetics and mechanisms of chlorine dioxide oxidation of tryptophan. Inorg Chem 47(5):1639-1647. https://doi.org/10. 1021/ic701761p

43. Loginova IV, Rubtsova SA, Kuchin AV (2008) Oxidation by chlorine dioxide of methionine and cysteine derivatives to sulfoxides. Chem Nat Compd 44(6):752-754. https://doi.org/10.1007/s10600009-9182-8

44. Nishikiori R, Nomura Y, Sawajiri M, Masuki K, Hirata I, Okazaki M (2008) Influence of chlorine dioxide on cell death and cell cycle of human gingival fibroblasts. J Dentistry 36(12):993-998. https:// doi.org/10.1016/j.jdent.2008.08.006

45. Herczegh A, Gyurkovics M, Ghidan Á, Megyesi M, Lohinai Z (2014) Effect of dentin powder on the antimicrobial properties of hyperpure chlorine-dioxide and its comparison to conventional endodontic disinfecting agents. Acta Microbiol Imm Hung. 61(2): 209-220. https://doi.org/10.1556/AMicr.61.2014.2.10

46. Li Y-C, Kuan Y-H, Lee S-S, Huang F-M, Chang Y-C (2014) Cytotoxicity and genotoxicity of chlorhexidine on macrophages in vitro. Environ Toxicol 29(4):452-458. https://doi.org/10.1002/ tox.21771

47. Fox SA, Currie SS, Dalley AJ, Farah CS (2018) Transcriptome changes induced in vitro by alcohol-containing mouthwashes in normal and dysplastic oral keratinocytes. J Oral Pathol Med 47(5):511-518. https://doi.org/10.1111/jop.12704

48. Durbakula K, Prabhu V, Jose M (2018) Genotoxicity of nonalcoholic mouth rinses: a micronucleus and nuclear abnormalities study with fluorescent microscopy. J Invest Clin Dentistry 9(2): e12309. https://doi.org/10.1111/jicd.12309

49. Yadav SR, Kini VV, Padhye A (2015) Inhibition of tongue coat and dental plaque formation by stabilized chlorine dioxide vs chlorhexidine mouthrinse: a randomized, triple blinded study. J Clin Diagn Res 9(9):ZC69-ZC74. Epub 2015/09/01. https://doi.org/10.7860/ JCDR/2015/14587.6510

50. Fráter M, Braunitzer G, Urbán E, Bereczki L, Antal M, Nagy K (2013) In vitro efficacy of different irrigating solutions against polymicrobial human root canal bacterial biofilms. Acta Microbiol Imm Hung. 60(2):187-199. https://doi.org/10.1556/ AMicr.60.2013.2.9

51. Tanner RS (1989) Comparative testing and evaluation of hardsurface disinfectants. J Ind Microbiol 4(2):145-154. https://doi. org/10.1007/BF01569799

Publisher's note Springer Nature remains neutral with regard to jurisdictional claims in published maps and institutional affiliations. 